\title{
DESIGN, SYNTHESIS, MOLECULAR DOCKING, AND ANTIBACTERIAL ACTIVITY EVALUATION OF SOME NOVEL NORFLOXACIN ANALOGUES
}

\author{
SMARANDA ONIGA ${ }^{1 \#}$, MARIANA PALAGE ${ }^{1}$, CĂTĂLIN ARANICIU ${ }^{1}$, GABRIEL MARC $^{2 \#}$, \\ OVIDIU ONIGA $^{2 *}$, LAURIAN VLASE $^{3}$, VIOREL PRISĂCARI ${ }^{4 *}$, VLADIMIR VALICA $^{5,6}$, \\ SERGHEI CURLAT ${ }^{7}$, LIVIA UNCU ${ }^{5,6}$ \\ 'Department of Therapeutic Chemistry, Faculty of Pharmacy, "Iuliu Hațieganu” University of Medicine and Pharmacy, \\ Cluj-Napoca, Romania \\ ${ }^{2}$ Department of Pharmaceutical Chemistry, Faculty of Pharmacy, “Iuliu Hațieganu” University of Medicine and Pharmacy, \\ Cluj-Napoca, Romania \\ ${ }^{3}$ Department of Pharmaceutical Technology and Biopharmacy, "Iuliu Hațieganu” University of Medicine and Pharmacy, \\ Cluj-Napoca, Romania \\ ${ }^{4}$ Epidemiology, Faculty of Medicine, "Nicolae Testemițanu" State University of Medicine and Pharmacy, Chișinău, Republic \\ of Moldova \\ ${ }^{5}$ Pharmaceutical Chemistry and Toxicology, Faculty of Pharmacy, "Nicolae Testemițanu" State University of Medicine and \\ Pharmacy, Chișinău, Republic of Moldova \\ ${ }^{6}$ Scientific Centre of Drug Research, "Nicolae Testemițanu" State University of Medicine and Pharmacy, Chișinău, Republic \\ of Moldova \\ ${ }^{7}$ Biochemistry and Clinical Biochemistry, Faculty of Medicine, "Nicolae Testemițanu" State University of Medicine and \\ Pharmacy, Chișinău, Republic of Moldova
}

*corresponding author: ooniga@umfcluj.ro

\#Authors with equal contribution

Manuscript received: June 2018

\begin{abstract}
A novel series of 7 or 3-substituted norfloxacin derivatives were synthesized and characterized by ${ }^{1} \mathrm{H}$ NMR, MS and elemental analysis techniques. All the synthesized compounds were evaluated for antimicrobial activity against both Gram-positive and Gram-negative bacteria and the MIC and MBC values were calculated by the broth dilution method. To understand the influence of the different type of substituents on the pharmacokinetic properties and the interaction with the target enzyme of fluoroquinolones (DNA gyrase), we performed a molecular docking study, and we calculated the ADMET properties.
\end{abstract}

\section{Rezumat}

O nouă serie de derivați ai norfloxacinei substituiţi în poziţiile 7 sau 3 au fost sintetizaţi şi caracterizaţi prin ${ }^{1} \mathrm{H}$ RMN, spectrometrie de masă şi analiză elementală. Toți compușii sintetizaţi au fost evaluaţi pentru activitatea antimicrobiană atât împotriva bacteriilor Gram-pozitive cât și a celor Gram-negative, iar valorile CMI și CMB au fost calculate prin metoda diluțiilor succesive. Pentru a înțelege influența acestor diferite tipuri de substituenți asupra proprietăților farmacocinetice și asupra interacțiunii cu enzima țintă a fluorochinolonelor (ADN giraza), a fost efectuat un studiu de andocare moleculară și au fost calculați parametrii ADMET.

Keywords: molecular docking, DNA gyrase, norfloxacin

\section{Introduction}

Antibiotic resistance and the resulting risk for ineffective treatment of infections are serious and growing problems. Antibiotic resistance kills an estimated number of 700,000 people each year worldwide and that number could raise to 10 million by 2050 if efforts are not made to limit resistance or develop new antibiotics, reveals the Review on Antimicrobial Resistance published in 2016 [29]. The number of new antibiotics in development is insufficient to mitigate the growing threat of anti- microbial resistance, according to a report launched by the World Health Organization in 2017 [42].

One of the strategies in the research for new antibiotics is focused on developing improved versions of existing molecules that are more efficient or less susceptible to resistance mechanisms. The fluoroquinolones class is one of the most widely used categories of antimicrobial agents in outpatient and inpatient treatment. They are characterized as broad-spectrum antibacterial drugs active against both Gram-positive and Gramnegative bacteria. Despite a large number of approved fluoroquinolones for the treatment of various infections, 
there have been constant efforts for the discovery of new fluoroquinolones with specific properties, such as desired pharmacokinetic profile, improved therapeutic index and most importantly devoid of bacterial resistance [12, 33, 34].

The minimal fluoroquinolone structure consists of a bicyclic system with a substituent at $\mathrm{N}-1$ position, a carboxyl group at 3 position, a oxo group at 4 position, a fluorine atom at 6 position and a substituent (often nitrogen based heterocycle moiety) at C-7 [31]. Since the introduction in therapy of norfloxacin, most of the fluoroquinolone antibacterial research has focused on the substituent at C-7 position [24].

In view of the reported antimicrobial activity of various fluoroquinolone derivatives $[10,13,16,35$, 39], the role of the C-7 substituents is that they are important for the broad spectrum and potency of fluoroquinolones [2, 11, 14, 37]. Moreover, chemical modifications at $\mathrm{C}-7$ are suitable for controlling the pharmacokinetic properties and the cell permeability of these antibiotics [3, 19, 41]. In addition, mechanism of action and structure-activity relationship studies of quinolones reveals that the $\mathrm{C}-7$ substituent is very important for the interaction with the target enzyme: DNA gyrase [8, 24, 36].

The C-3 carboxylic acid group is considered essential for the antimicrobial activity; therefore, there is much less data in the literature about analogues of fluoroquinolones with modifications at the carboxylic group. However, significant improvement in antibacterial activity was observed with the introduction of sulphonamide or carboxamide group in $\mathrm{C} 3$ position of fluoroquinolones [32, 38]. Also, a fused izothiazolone ring that replaced the carboxyl group led to a larger spectrum of activity [32].

All the above mentioned data motivated our effort to develop some C-7 substituted analogues of norfloxacin (which has a poor oral bioavailability [21] and a short half-life) at the piperazine moiety by replacing the hydrogen at 4 position with different substituents that were chosen considering their variable lipophilicities, molecular masses or steric properties. We proposed also, the synthesis of a new derivative in which the carboxyl group is replaced by a thiadiazol nucleus in order to compare the influence of this type of modification on the antibacterial activity and interaction with DNA gyrase.

To understand the influence of these different types of substituents on the pharmacokinetic properties and the interactions with DNA gyrase, we performed a molecular docking study and calculated ADMET properties.

\section{Materials and Methods}

Chemical protocols

All chemicals and reagents were obtained from commercial sources and were used as supplied, without further purification. The uncorrected melting points were determined using an MPM-H1 Schorpp melting point meter in open glass capillary.

The purity of the synthesized compounds was verified by thin layer chromatography (TLC) and was carried out on pre-coated Silica Gel $60 \mathrm{~F}_{254}$ sheets using acetone:methanol 5:3 and UV absorption for visualization.

The ${ }^{1} \mathrm{H}$ NMR spectra were recorded at room temperature on a Bruker Avance NMR spectrometer operating at $500 \mathrm{MHz}$. Chemical shift values were reported relative to tetramethylsilane (TMS) as internal standard. The samples were prepared by dissolving the synthesized powder of the compounds in DMSO $d 6(\delta \mathrm{H}=2.51$ ppm) as solvent and the spectra were recorded using a single excitation pulse of $12 \mu \mathrm{s}$.

MS analyses were performed on an Agilent 1100 series, in positive ionization with an Agilent Ion Trap SL mass spectrometer $(70 \mathrm{eV})$. Elemental analysis was registered with a Vario El CHNS instrument. All new compounds yielded spectral data consistent with the proposed structure and microanalysis within $0.4 \%$ of the theoretical values.

Compound $\mathbf{5}$ was previously reported and was synthesized using adapted methodologies described in the literature [5].

Synthesis of 1-ethyl-6-fluoro-4-oxo-7-(4-((2-phenylthiazol-4-yl)methyl)piperazin-1-yl)-1,4-dihydro-

quinoline-3-carboxylic acid (1)

A mixture of norfloxacin $(3 \mathrm{mmol})$ and $\mathrm{K}_{2} \mathrm{CO}_{3}(3.3$ mmol) was stirred in DMF $(30 \mathrm{~mL})$ at room temperature for 20 minutes. To the resulted mixture, the 4-(iodomethyl)-2-phenylthiazole $(3.3 \mathrm{mmol})$ in DMF $(10 \mathrm{~mL})$, was added dropwise over a period of 10 minutes. The reaction mixture was further stirred at room temperature for $24 \mathrm{~h}$, poured into cold water and neutralised with sulphuric acid $10 \%$ until the complete precipitation. The solid formed was filtered, washed with cold water and crystallised from the appropriate solvent.

(1): $\mathrm{C}_{26} \mathrm{H}_{25} \mathrm{FN}_{4} \mathrm{O}_{3} \mathrm{~S}$, white powder, 74\% yield, m.p. $186-188^{\circ} \mathrm{C}$; MS (EI, $\left.70 \mathrm{eV}\right): \mathrm{m} / \mathrm{z}=493(\mathrm{M}+1),{ }^{1} \mathrm{H}$ NMR (DMSO-d6, $\delta, \mathrm{ppm}), \delta: 15.45$ (s, 1H, COOH), 9.1 (s, 1H, $\mathrm{C}_{2}$-quinolone), 8.4 - $7.9(\mathrm{~m}, 5 \mathrm{H}$, phenyl), $7.95\left(\mathrm{~s}, 1 \mathrm{H}\right.$, thiazole $\left.\mathrm{C}_{5}\right), 7.78\left(\mathrm{~d}, 1 \mathrm{H}, \mathrm{C}_{5}\right.$-quinolone), 7.25 (d, $1 \mathrm{H}, \mathrm{C}_{8}$-quinolone), $4.46\left(\mathrm{q}, 2 \mathrm{H}, \mathrm{CH}_{2}-\mathrm{CH}_{3}\right)$, 3.45 (s, 2H, $\mathrm{CH}_{2}$-thiazole- $\left.\mathrm{C}_{4}\right), 3.3-3.1(\mathrm{~m}, 8 \mathrm{H}$, $4 \mathrm{CH}_{2}$-piperazine), $1.46\left(\mathrm{t}, 3 \mathrm{H},-\mathrm{CH}_{2}-\mathrm{CH}_{3}\right)$.

General procedure for the synthesis of norfloxacin derivatives (2-4)

Norfloxacin $(3 \mathrm{mmol}$ ) was dissolved in $30 \mathrm{~mL}$ of anhydrous tetrahydrofuran (THF). To this solution, triethylamine (1 molar equivalent) and 1.5 molar equivalent of appropriate acyl chloride were added and the resultant mixture was refluxed till the completion of the reaction, monitored by TLC. The resultant mixture was then cooled to room temperature and excess solvent was removed on a rotary evaporator. The 
crude product was crystallised from the appropriate solvent.

(2): 7-(4-(3-chlorobenzoyl)piperazin-1-yl)-1-ethyl-6fluoro-4-oxo-1,4-dihydroquinoline-3-carboxylic acid: $\mathrm{C}_{23} \mathrm{H}_{21} \mathrm{ClFN}_{3} \mathrm{O}_{4}$, white powder, 80\% yield, m.p. 218 $220^{\circ} \mathrm{C}$; MS (EI, $70 \mathrm{eV}$ ): $\mathrm{m} / \mathrm{z}=458.3$ and $460.1,{ }^{1} \mathrm{H}$ NMR (DMSO-d6, $\delta, \mathrm{ppm}), \delta: 15.29$ (s, 1H, COOH), 9.0 (s, 1H, $\mathrm{C}_{2}$-quinolone), 7.91 (d, 1 $\mathrm{H}, \mathrm{C}_{5}$-quinolone), 7.6 - 7.95 (m 4H, phenyl), 7.20 (d 1H, $\mathrm{C}_{8}$-quinolone), $4.46\left(\mathrm{q}, 2 \mathrm{H}, \mathrm{CH}_{2}-\mathrm{CH}_{3}\right), 3.4-2.97\left(\mathrm{~m}, 8 \mathrm{H}, 4 \mathrm{CH}_{2}-\right.$ piperazine), $1.42\left(\mathrm{t}, 3 \mathrm{H}, \mathrm{CH}_{2}-\mathrm{CH}_{3}\right)$.

(3): 1-ethyl-6-fluoro-7-(4-(furan-2-carbonyl)piperazin1-yl)-4-oxo-1,4-dihydroquinoline-3-carboxylic acid: $\mathrm{C}_{21} \mathrm{H}_{20} \mathrm{FN}_{3} \mathrm{O}_{5}$, white powder, $81 \%$ yield, m.p. $>250^{\circ} \mathrm{C}$ (dec.); MS (EI, $70 \mathrm{eV}): \mathrm{m} / \mathrm{z}=414(\mathrm{M}+1),{ }^{1} \mathrm{H}$ NMR (DMSO-d6, $\delta$, ppm), $\delta: 14.6$ (s, 1H, COOH), 9.0 (s, 1H, $\mathrm{C}_{2}$-quinolone), 8.19 - 8.62 (m, $3 \mathrm{H}$, furan), 7.93 (d, $1 \mathrm{H}, \mathrm{C}_{5}$-quinolone), 7.23 (d, 1H, $\mathrm{C}_{8}$-quinolone), 4.72 (q, $\left.2 \mathrm{H}, \mathrm{CH}_{2}-\mathrm{CH}_{3}\right), 3.13$ - 3.08 (m, $8 \mathrm{H}, 4 \mathrm{CH}_{2}$-piperazine), $1.40\left(\mathrm{t}, 3 \mathrm{H}, \mathrm{CH}_{2}-\mathrm{CH}_{3}\right)$.

(4): 1-ethyl-6-fluoro-7-(4-isobutyrylpiperazin-1-yl)4-oxo-1,4-dihydroquinoline-3-carboxylic acid: $\mathrm{C}_{20} \mathrm{H}_{24} \mathrm{FN}_{3} \mathrm{O}_{4}$, white powder, 84\% yield, m.p. 248 $250^{\circ} \mathrm{C}$; MS (EI, $\left.70 \mathrm{eV}\right): \mathrm{m} / \mathrm{z}=390(\mathrm{M}+1),{ }^{1} \mathrm{H}$ NMR (DMSO-d6, $\delta, \mathrm{ppm}), \delta: 15.2(\mathrm{~s}, 1 \mathrm{H}, \mathrm{COOH}), 9.2$ (s, $1 \mathrm{H}, \mathrm{C}_{2}$-quinolone), 7.93 (d, $1 \mathrm{H}, \mathrm{C}_{5}$-quinolone), 7.23 (d, $1 \mathrm{H}, \mathrm{C}_{8}$-quinolone), 4.72 (q, $2 \mathrm{H}, \mathrm{CH}_{2}-\mathrm{CH}_{3}$ ), 3.13 3.08 (m, 8H, 4CH $\mathrm{CH}_{2}$-piperazine), 2.94 ( $\mathrm{m}, 1 \mathrm{H}$, isobutyryl), $1.44\left(\mathrm{t}, 3 \mathrm{H}, \mathrm{CH}_{2}-\mathrm{CH}_{3}\right), 1.04$ (d, 6H, isobutyryl).

General procedure for the synthesis of norfloxacin derivatives (5-9)

A mixture of norfloxacin ( $3 \mathrm{mmol}), \mathrm{K}_{2} \mathrm{CO}_{3}(6 \mathrm{mmol})$, and appropriate alpha bromo-ketones $(3 \mathrm{mmol})$ in dimethyl formamide $(40 \mathrm{~mL})$ was stirred at room temperature for 24 hours. The reaction mixture was poured over ice water $(50 \mathrm{~mL})$. The separated solid were collected by filtration, dried, and purified by recrystallization from methanol.

(5): 1-ethyl-6-fluoro-4-oxo-7-(4-(2-oxo-2-phenylethyl)piperazin-1-yl)-1,4-dihydroquinoline-3-carboxylic acid: $\mathrm{C}_{24} \mathrm{H}_{24} \mathrm{FN}_{3} \mathrm{O}_{4}$, white powder, $82 \%$ yield, m.p. $212-214^{\circ} \mathrm{C}$ (dec.); MS (EI, $\left.70 \mathrm{eV}\right): \mathrm{m} / \mathrm{z}=438(\mathrm{M}+1)$, ${ }^{1} \mathrm{H}$ NMR (DMSO-d6, $\delta$, ppm) $\delta: 15.33$ (s, 1H, COOH), 9.2 (s, 1H, $\mathrm{C}_{2}$-quinolone), 7.83 (d, 1H, $\mathrm{C}_{5}$-quinolone), 7.79 - 7.36 (m, 5H, phenyl), 7.2 (d, 1H, $\mathrm{C}_{8}$-quinolone), 4.72 (q, 2H, $\left.\mathrm{CH}_{2}-\mathrm{CH}_{3}\right), 3.7\left(\mathrm{~s}, 2 \mathrm{H}, \mathrm{N}-\mathrm{CH}_{2}\right), 3.39-$ 3.08 (m, 8H, 4CH -piperazine), $1.46\left(\mathrm{t}, 3 \mathrm{H}, \mathrm{CH}_{2}-\mathrm{CH}_{3}\right)$. (6): 1-ethyl-6-fluoro-4-oxo-7-(4-(1-oxo-1-phenylpropan-2-yl)piperazin-1-yl)-1,4-dihydroquinoline-3carboxylic acid: $\mathrm{C}_{25} \mathrm{H}_{26} \mathrm{FN}_{3} \mathrm{O}_{4}$, white powder, 79\% yield, m.p. $234-235^{\circ} \mathrm{C}$ (d); MS (EI, $70 \mathrm{eV}$ ): m/z = 452 $(\mathrm{M}+1),{ }^{1} \mathrm{H}$ NMR (DMSO-d6, $\left.\delta, \mathrm{ppm}\right), \delta: 15.36$ (s, $1 \mathrm{H}, \mathrm{COOH}), 8.98$ (s, 1H, $\mathrm{C}_{2}$-quinolone), 7.92 (d, $1 \mathrm{H}, \mathrm{C}_{5}$-quinolone), 7.85 - 7.4 (m, 5H, phenyl), 7.15 (d, $1 \mathrm{H}, \mathrm{C}_{8}$-quinolone), 4.62 (q, $2 \mathrm{H}, \mathrm{CH}_{2},-\mathrm{C}_{2} \mathrm{H}_{5}$ ), 4.58 (m, 1H, N-CH), 3.86 (s, 2H, N-CH $)$, 3.24 - 2.97 (m, $8 \mathrm{H}, 4 \mathrm{CH}_{2}$-piperazine), 1.4 (t, $\left.3 \mathrm{H} \mathrm{CH}_{2}-\mathrm{CH}_{3}\right), 1.3$ (m, $3 \mathrm{H}, \mathrm{CH}_{2}-\mathrm{CH}_{3}$ ).
(7): 7-(4-(2-(4-bromophenyl)-2-oxoethyl)piperazin1-yl)-1-ethyl-6-fluoro-4-oxo-1,4-dihydroquinoline-

3-carboxylic acid: $\mathrm{C}_{24} \mathrm{H}_{23} \mathrm{BrFN}_{3} \mathrm{O}_{4}$, white powder, $85 \%$ yield, m.p.: $>250^{\circ} \mathrm{C}$ (dec.); MS (EI, $70 \mathrm{eV}$ ): $\mathrm{m} / \mathrm{z}=517$ and $519,{ }^{1} \mathrm{H}$ NMR (DMSO-d6, $\delta, \mathrm{ppm}$ ) $\delta: 15.28(\mathrm{~s}, 1 \mathrm{H}, \mathrm{COOH}), 9.2\left(\mathrm{~s}, 1 \mathrm{H}, \mathrm{C}_{2}\right.$-quinolone), $8.58-7.30\left(\mathrm{~m}, 7 \mathrm{H}\right.$, naphthyl), $7.83\left(\mathrm{~d}, 1 \mathrm{H}, \mathrm{C}_{5^{-}}\right.$ quinolone), 7.2 (d, 1H, $\mathrm{C}_{8}$-quinolone), 4.5 (q, 2H, $\left.\mathrm{CH}_{2}-\mathrm{CH}_{3}\right), 3.39-3.08\left(\mathrm{~m}, 10 \mathrm{H}, 4 \mathrm{CH}_{2}\right.$-piperazine, $\left.\mathrm{N}-\mathrm{CH}_{2}\right), 1.42\left(\mathrm{t}, 3 \mathrm{H}, \mathrm{CH}_{2}-\mathrm{CH}_{3}\right)$.

(8): 1-ethyl-6-fluoro-7-(4-(2-(naphthalen-1-yl)-2-oxoethyl)piperazin-1-yl)-4-oxo-1,4-dihydroquinoline-3carboxylic acid: $\mathrm{C}_{28} \mathrm{H}_{26} \mathrm{FN}_{3} \mathrm{O}_{4}$, white powder, $75 \%$ yield, m.p. $220-222^{\circ} \mathrm{C}$; MS (EI, $\left.70 \mathrm{eV}\right): \mathrm{m} / \mathrm{z}=488$ $(\mathrm{M}+1),{ }^{1} \mathrm{H}$ NMR (DMSO-d6, $\left.\delta, \mathrm{ppm}\right), \delta: 15.32$ (s, $1 \mathrm{H}, \mathrm{COOH}$ ), 9.2 (s, 1H, $\mathrm{C}_{2}$-quinolone), 8.32 (q, $2 \mathrm{H}$, phenyl $\mathrm{C}_{2}, \mathrm{C}_{6}$ ), 7.84 (q, 2H, phenyl $\left.\mathrm{C}_{3}, \mathrm{C}_{5}\right), 7.72(\mathrm{~d}$, $1 \mathrm{H}, \mathrm{C}_{5}$-quinolone), 7.19 (d, 1H, $\mathrm{C}_{8}$-quinolone), 4.5 (q, $\left.2 \mathrm{H}, \mathrm{CH}_{2}-\mathrm{CH}_{3}\right), 3.39$ - 3.08 (m, $10 \mathrm{H}, 4 \mathrm{CH}_{2}$-piperazine, $\left.\mathrm{N}-\mathrm{CH}_{2}\right), 1.4$ (t, $\left.3 \mathrm{H}, \mathrm{CH}_{2}-\mathrm{CH}_{3}\right)$.

(9): 7-(4-(2-amino-2-oxoethyl)piperazin-1-yl)-1-ethyl6-fluoro-4-oxo-1,4-dihydroquinoline-3-carboxylic acid: $\mathrm{C}_{18} \mathrm{H}_{21} \mathrm{FN}_{4} \mathrm{O}_{4}$, white powder, $71 \%$ yield, m.p. $>250^{\circ} \mathrm{C}($ dec.) $)$ MS (EI, $\left.70 \mathrm{eV}\right): \mathrm{m} / \mathrm{z}=377(\mathrm{M}+1)$, ${ }^{1} \mathrm{H}$ NMR (DMSO-d6, $\left.\delta, \mathrm{ppm}\right), \delta: 15.34$ (s, 1H, COOH), 9.2 (s, 1H, $\mathrm{C}_{2}$-quinolone), 7.72 (d, 1H, $\mathrm{C}_{5}$-quinolone), 7.19 (d, 1H, $\mathrm{C}_{8}$-quinolone), 7.16 (s, 2H, $\mathrm{NH}_{2}$ ), 4.5 (q, $\left.2 \mathrm{H}, \mathrm{CH}_{2}-\mathrm{CH}_{3}\right), 3.5$ (s, 2H, N-CH $), 3.39-3.08$ (m, $8 \mathrm{H}, 4 \mathrm{CH}_{2}$-piperazine), $1.4\left(\mathrm{t}, 3 \mathrm{H}, \mathrm{CH}_{2}-\mathrm{CH}_{3}\right)$.

Synthesis of 3-(5-amino-1,3,4-thiadiazol-2-yl)-1ethyl-6-fluoro-7-(piperazin-1-yl)quinolin-4(1H)-one derivative 10

A mixture of norfloxacin ( $3 \mathrm{mmol})$, thiosemicarbazide ( $3 \mathrm{mmol}$ ) and $3 \mathrm{~mL}$ of phosphorus oxychloride was refluxed gently for 40 minutes. After cooling, $9 \mathrm{~mL}$ of water were added gradually. The resulted solution was refluxed for $4 \mathrm{~h}$ and left at room temperature for $24 \mathrm{~h}$. The separated solid was collected by filtration and purified by recrystallization from ethanol.

(10): 3-(5-amino-1,3,4-thiadiazol-2-yl)-1-ethyl-6fluoro-7-(piperazin-1-yl)quinolin-4(1H)-one derivative: $\mathrm{C}_{17} \mathrm{H}_{19} \mathrm{FN}_{6} \mathrm{OS}$, orange powder, $45 \%$ yield, m.p. $>$ $250^{\circ} \mathrm{C}$ (dec.); MS (EI, $\left.70 \mathrm{eV}\right): \mathrm{m} / \mathrm{z}=376(\mathrm{M}+1),{ }^{1} \mathrm{H}$ NMR (DMSO-d6, $\delta, \mathrm{ppm}), \delta: 11.32\left(\mathrm{~s}, 2 \mathrm{H}, \mathrm{NH}_{2}\right)$, $9.14\left(\mathrm{~s}, 1 \mathrm{H}, \mathrm{C}_{2}\right.$-quinolone), $8.52\left(\mathrm{~d}, 1 \mathrm{H}, \mathrm{C}_{5^{-}}\right.$ quinolone), 7.78 (d, $1 \mathrm{H}, \mathrm{C}_{8}$-quinolone), $4.72(\mathrm{q}, 2 \mathrm{H}$, $\left.\mathrm{CH}_{2}-\mathrm{CH}_{3}\right), 3.45-3.08$ (m, $8 \mathrm{H}, 4 \mathrm{CH}_{2}$-piperazine), 3.35 (br, s, $1 \mathrm{H}, \mathrm{NH}), 1.46\left(\mathrm{t}, 3 \mathrm{H}, \mathrm{CH}_{2}-\mathrm{CH}_{3}\right)$.

The quantitative assay of the minimal inhibitory concentration (MIC) and minimum bactericidal concentration $(M B C)$

The antimicrobial activities of the newly synthesized compounds were determined against bacterial strains such as: Staphylococcus aureus t209, Enterococus faecalis ATCC 19433, Escherichia coli ATCC 25922, Pseudomonas aeruginosa ATCC 27853, Klebsiella pneumoniae t3534/51, Proteus vulgaris tHX 19222 and clinically isolated strains of Salmonella typhimurium 
FARMACIA, 2018, Vol. 66, 6

and Acinetobacter baumannii. The microbial strains used were obtained from the collection of the Epidemiology Department, Faculty of Medicine, "Nicolae Testemițanu" State University of Medicine and Pharmacy Chișinău, Republic of Moldova. Stock solutions $(1 \mathrm{mg} / \mathrm{mL})$ were prepared by dissolving the test compounds and the reference antibiotic (norfloxacin), respectively, in sterile DMF. These solutions were stored at $4^{\circ} \mathrm{C}$. Series of double diluting solutions of the above compounds were prepared in peptone broth medium, obtaining final concentrations in the range of $300 \mu \mathrm{g} / \mathrm{mL}$ to $0.15 \mu \mathrm{g} / \mathrm{mL}$. Each well was seeded with $20 \mu \mathrm{L}$ microbial inoculum of 0.5 McFarland density and incubated for $24 \mathrm{~h}$ at $37^{\circ} \mathrm{C}$. Growth control and sterility control were used. The MICs were read as the lowest concentration of the tested compound, expressed in $\mu \mathrm{g} / \mathrm{mL}$, which inhibited visible microbial growth. For determining the minimum bactericidal concentration (MBC), a $0.01 \mathrm{~mL}$ aliquot of the medium drawn from the culture tubes showing no macroscopic growth after $24 \mathrm{~h}$, was sub-cultured on nutrient of peptone agar and incubated further at $37^{\circ} \mathrm{C}$ for $24 \mathrm{~h}$, to determine the number of vital organisms. The MBC's were read as the lowest concentration of the tested compounds to achieve a bactericidal effect [1].

Calculation of ADMET parameters

The new compounds were subjected to a theoretical in silico ADME and toxicity prediction study using Swiss-ADME [6] and FAF-Drugs [20]. The structural parameters of the new molecules were evaluated based on Lipinski (Pfizer) [22], Veber (Glaxo Smith Kline) [40], Muegge (Bayer) [27] and Egan [9] rules. ADMET parameters such as: polarity, lipophilicity, water solubility, gastrointestinal absorption, P-glycoprotein substrate, blood brain barrier (BBB) permeability, CYP450 inhibition and phospholipidosis (PLD) induction were predicted.

\section{Molecular docking study}

In order to understand the binding mechanism of the newly synthesized compounds to the bacterial gyrase, a molecular docking study was performed using AutoDock 4.2 [26]. Our compounds were subjected to docking against the bacterial gyrase isolated from Staphylococcus aureus, in order to evaluate the binding affinity, the inhibition constant and possible interactions that can occur with the enzyme. The source of the protein was Protein Data Bank (entry code of the 3D structure: $2 \mathrm{XCT}$ ). The input ligand files of the compounds 1-10 and the target were prepared according a previously reported protocol $[4$, 25] using AutoDock Tools 1.5.6 [26]. 20 theoretical conformations were searched for each ligand. Search space was defined as cubic, with sides dimensions equal to $\mathrm{x}=\mathrm{y}=\mathrm{z}=65$, with the centre coordinates set to $x=-13.224, y=34.775, z=68.297$. In this search space, the molecule of ciprofloxacin was previously found co-crystallized in the $2 \mathrm{XCT}$ structure.
Predicted inhibition constant of the compounds (ki) was calculated based on the computed binding affinity energy $(\Delta G)$, using the reported protocol [25].

In order to remove the false positive results from the molecular docking, a pose clustering was performed. A maximum root mean square deviation limit between the poses coordinates was set to $2 \AA$. Clustering analyses is considered a potential tool useful in removing the false positive results of the compounds that have large dispersion in the binding pattern. The pose clustering is used to find the acceptable poses which appear repetitively between multiple docking experiments. A ligand with a high dispersion of binding poses is characterized by having few conformations in each cluster and a large number of clusters due to chaotic binding in the active site of the enzyme [18, 23]. We established as a rule for the acceptance of docking poses results for a compound, that at least a third of conformations have to be in the top binding cluster (at least 7 conformations out of 20) and the maximum number of clusters should be 10 . Visualization of the docking results was performed using UCSF Chimera [30].

\section{Results and Discussion}

\section{Chemistry}

The synthesis of the desired compounds is outlined in Figure 1.

Synthesis of compound $\mathbf{1}$ was performed by the reaction of norfloxacin with 2-phenyl-4-iodo-methylthiazole, in dry DMF and potassium carbonate, at room temperature for $24 \mathrm{~h}$.

The treatment of norfloxacin with different acyl halides and triethylamine, in anhydrous tetrahydrofuran at reflux, gave the compounds $\mathbf{2 - 4}$.

Compounds 5-9 were obtained by the reaction of norfloxacin with different alpha halo-ketones and potassium carbonate, in dry DMF, at room temperature. Finally, compound $\mathbf{1 0}$ was obtained by the reaction of norfloxacin with thiosemicarbazide and phosphorus oxychloride at reflux.

The structures of the newly synthesized compounds were elucidated by the combined use of ${ }^{1} \mathrm{H} \mathrm{NMR}$, mass spectral data and elemental analysis.

The ${ }^{1} \mathrm{H}$ NMR spectrum of all the compounds showed multiple signals corresponding to resonance of fluoroquinolone moiety protons. Compounds 1-9 showed the characteristic signal of the carboxylic acid proton as a singlet in the region of $\delta 14.6-15.4 \mathrm{ppm}$, while compound 10 showed a characteristic signal for unsubstituted piperazine $\mathrm{NH}$, as broad singlet at $\delta 3.35$ ppm. Compound 1 exhibited a singlet signal at $\delta 7.95$ ppm, which was attributed to the proton at the $\mathrm{C}_{5}$ position of the thiazole nucleus, and characteristic signals in the range of $\delta 7.0-8.4 \mathrm{ppm}$, due to the aromatic protons of the phenyl in $\mathrm{C}_{2}$ position of the thiazole moiety. Compounds 2-4 exhibited characteristic 
FARMACIA, 2018, Vol. 66, 6

signals attributed to the N-piperazine substituent ( $m$ Cl-phenyl, furan, isobutyl). Compounds 5-9 exhibited a singlet signal in the range of $\delta 2.97-3.86 \mathrm{ppm}$, attributed to the piperazine methylene bridge $\mathrm{N}-\mathrm{CH}_{2}$,

and also the characteristic signals for each type of substituent.

Finally, compound $\mathbf{1 0}$ presented a singlet signal at $\delta$ $11.32 \mathrm{ppm}$, attributed to the amino protons of the thiadiazole moiety.

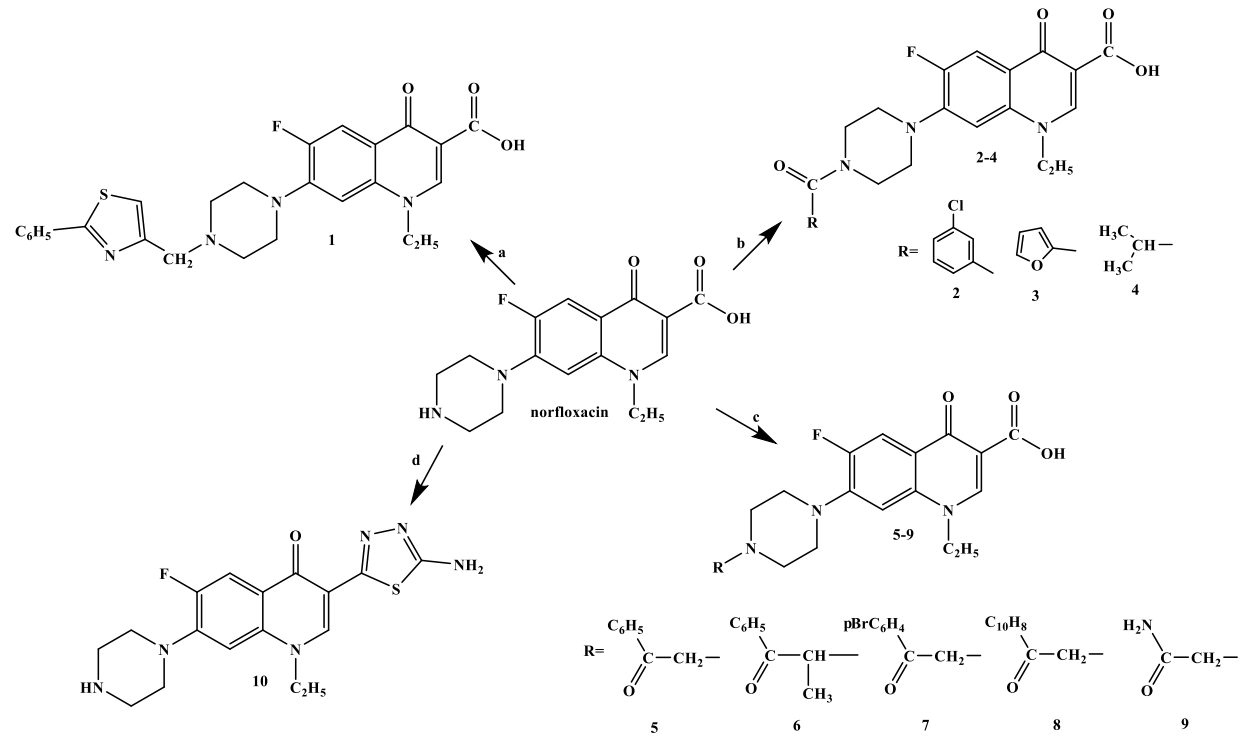

Figure 1.

The chemical synthesis of the desired compounds;

a: 2-phenyl-4-iodo-methyl-thiazole/dry DMF/ $\mathrm{K}_{2} \mathrm{CO}_{3} /$ r.t./24 h; b: acyl halides/TEA/THF/reflux; c: alpha halo-ketones/dry DMF/ $\mathrm{K}_{2} \mathrm{CO}_{3} /$ r.t. $/ 24 \mathrm{~h}$; d: thiosemicarbazide $/ \mathrm{POCl}_{3} / \mathrm{reflux}$

Biological evaluation

The broth microdilution method was employed for the MIC and MBC tests.

The antimicrobial activity of the synthesized compounds was assessed on both Gram-positive and Gramnegative microbial strains: Staphylococcus aureus t209, Enterococus faecalis ATCC 19433, Escherichia coli ATCC 25922, Pseudomonas aeruginosa ATCC 27853, Klebsiella pneumoniae $\mathrm{t} 3534 / 51$, Proteus vulgaris tHX 19222, Salmonella typhimurium and Acinetobacter baumannii.

The obtained results are presented in Table I.

Table I

Results of antibacterial activity: MIC and MBC expressed in $\mu \mathrm{g} / \mathrm{mL}$

\begin{tabular}{|c|c|c|c|c|c|c|c|c|c|c|c|c|c|c|c|c|}
\hline \multirow[t]{2}{*}{ 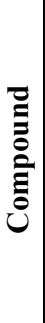 } & \multicolumn{2}{|c|}{ 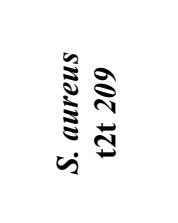 } & \multicolumn{2}{|c|}{ 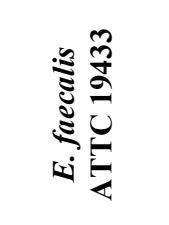 } & \multicolumn{2}{|c|}{ 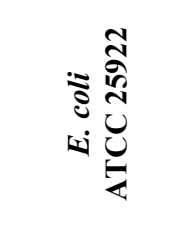 } & \multicolumn{2}{|c|}{ 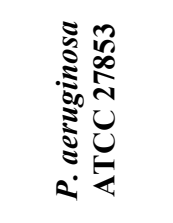 } & \multicolumn{2}{|c|}{ 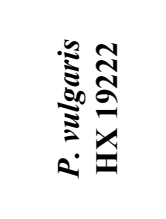 } & \multicolumn{2}{|c|}{ 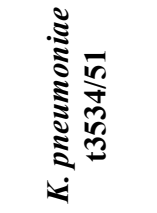 } & \multicolumn{2}{|c|}{ 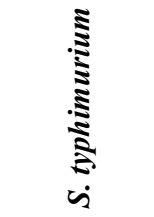 } & \multicolumn{2}{|c|}{ 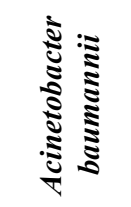 } \\
\hline & $\stackrel{\circlearrowright}{\sum}$ & $\underset{\Sigma}{\text { U. }}$ & $\stackrel{\circlearrowright}{\Sigma}$ & 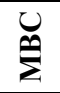 & $\stackrel{U}{\Sigma}$ & $\begin{array}{l}\text { U } \\
\sum_{\Sigma}\end{array}$ & $\stackrel{U}{\sum}$ & $\begin{array}{l}U \\
\sum\end{array}$ & $\stackrel{U}{\Sigma}$ & $\begin{array}{l}U \\
\sum\end{array}$ & $\stackrel{U}{\Sigma}$ & $\begin{array}{l}U \\
\sum\end{array}$ & $\stackrel{U}{\Sigma}$ & 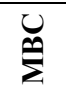 & $\stackrel{U}{\Sigma}$ & $U_{\Sigma}^{U}$ \\
\hline 1 & 150 & 300 & 150 & 300 & 18.75 & 300 & 150 & 150 & 300 & 300 & 300 & 300 & 75 & 300 & 300 & 300 \\
\hline 2 & 2.3 & 18.75 & 300 & 300 & 18.75 & 18.75 & 150 & 300 & 150 & 150 & $\mathrm{x}$ & $x$ & 300 & $\mathrm{x}$ & $\mathrm{x}$ & $\mathrm{x}$ \\
\hline \begin{tabular}{l|l|}
3 \\
\end{tabular} & 4.6 & 4.6 & 150 & 150 & 4.6 & 4.6 & $\mathrm{x}$ & $x$ & $x$ & $\mathrm{x}$ & $x$ & $x$ & $x$ & $x$ & $x$ & $\mathrm{x}$ \\
\hline 4 & 2.3 & 2.3 & 2.3 & 150 & 2.3 & 150 & 75 & $\mathrm{x}$ & 37.5 & 150 & $\mathrm{x}$ & $\mathrm{x}$ & 9.37 & $\mathrm{x}$ & $\mathrm{x}$ & $\mathrm{x}$ \\
\hline 5 & 0.145 & 4.6 & $\mathrm{x}$ & $\mathrm{x}$ & 1.17 & 37.5 & 150 & 150 & 37.5 & 37.5 & $\mathrm{x}$ & $\mathrm{x}$ & 9.37 & 37.5 & $x$ & $\mathrm{x}$ \\
\hline 6 & 0.145 & 9.37 & $\mathrm{x}$ & $\mathrm{x}$ & 4.6 & 150 & $x$ & $\mathrm{x}$ & $\mathrm{x}$ & $\mathrm{x}$ & $x$ & $\mathrm{x}$ & $\mathrm{x}$ & $\mathrm{x}$ & $x$ & $\mathrm{x}$ \\
\hline 7 & 4.6 & 300 & 300 & 300 & 18.75 & 300 & 18.75 & 150 & 4.68 & 300 & 2.34 & 300 & $\mathrm{x}$ & $\mathrm{x}$ & $x$ & $\mathrm{x}$ \\
\hline 8 & 300 & 300 & 150 & 150 & 300 & 300 & $x$ & $\mathrm{x}$ & 4.68 & 300 & $x$ & $\mathrm{x}$ & $x$ & $\mathrm{x}$ & $x$ & $\mathrm{x}$ \\
\hline 9 & 1.17 & 300 & 18.75 & 300 & 9.37 & 300 & 150 & 300 & 37.5 & $\mathrm{x}$ & 18.75 & $\mathrm{x}$ & 300 & 300 & $x$ & $\mathrm{x}$ \\
\hline 10 & 18.75 & $x$ & 150 & $x$ & 18.75 & $x$ & 75 & $x$ & 18.75 & $\mathrm{x}$ & $\mathrm{x}$ & $\mathrm{x}$ & 75 & $\mathrm{x}$ & $x$ & $\mathrm{x}$ \\
\hline $\mathbf{N}$ & 0.145 & 75 & 1.17 & 150 & 0.145 & 150 & 0.58 & 37.5 & 0.145 & 9.37 & 4.68 & 300 & 4.68 & 300 & 300 & 300 \\
\hline
\end{tabular}


FARMACIA, 2018, Vol. 66, 6

The four types of norfloxacin derivatives showed varying degrees of activity against different strains of bacteria.

The piperazinyl-methylen-phenylthiazole derivative 1 showed a lack of activity against the tested strains except for $E$. coli strain (MIC $=18.75 \mu \mathrm{g} / \mathrm{mL}$ ).

The acyl-piperazine derivatives 2-4 were active especially against the Gram-positive strains like $S$. aureus and E. faecalis (MIC $2.3-4.6 \mu \mathrm{g} / \mathrm{mL}$ ). In this series, the most active compound was compound 4 , a isobutyl-oxy derivative, active also against the Gramnegative bacteria like $E$. coli (MIC $2.3 \mu \mathrm{g} / \mathrm{mL}$ ) and $S$. typhimurium (MIC $9.3 \mu \mathrm{g} / \mathrm{mL}$ ). It seems that in this series, substitution with bulky residues (3-chlorophenyl in compound $\mathbf{2}$ and furan in compound $\mathbf{3}$ ) was unfavourable.

For the 2-oxoethyl-piperazine derivatives 5-9, the antimicrobial activity is expressed especially against the $S$. aureus strain, the most active compounds were 5, 6 and 9 (MIC $0.145-1.17 \mu \mathrm{g} / \mathrm{mL}$ ). The least active compound in this series was compounds 8 , a bulky (naphtyl) derivative, which led us to the conclusion that the substitution with large substituents was unfavourable in this series too.

Finally, the amino-thiadiazol derivative $\mathbf{1 0}$ was less active, the best MIC were $18.5 \mu \mathrm{g} / \mathrm{mL}$ and were expressed against $S$. aureus, E. coli and $P$. vulgaris.
All the compounds were less active or equipotent compared with the reference drug (norfloxacin), except compound 7 against $K$. pneumoniae $(\mathrm{MIC}=2.34$ $\mu \mathrm{g} / \mathrm{mL}$ compared with $4.68 \mu \mathrm{g} / \mathrm{mL}$ for norfloxacin). Also, some of the compounds $(\mathbf{2}, \mathbf{3}, \mathbf{4}, \mathbf{5}$ and $\mathbf{6})$ have lower MBC values (meaning a superior bactericidal activity) against $S$. aureus strain compared with the reference drug.

ADMET study

The results of the ADMET virtual screening are presented in Tables II - IV.

According to Lipinski's "rule of 5", the poor absorption or permeation of a compound is most likely when, there are more than $5 \mathrm{H}$-bond donors, the molecular weight is above 500 , the cLogP is above 5 and there are more than $10 \mathrm{H}$-bond acceptors.

Except compound 7 (molecular weight $=516$ ), all our compounds respect these theoretical limits. Compounds 1-9 have a negative charge at physiological $\mathrm{pH}$, due to the ionization of the carboxylic moiety. Compound 10, where the carboxylic moiety was converted into an amino-thiadiazole ring, is predicted to have a cationic state at physiological $\mathrm{pH}$, due to the protonation of the aromatic amine. Results are presented in Table II.

Table II

Structural analysis of compounds 1-10

\begin{tabular}{|c|c|c|c|c|c|c|c|c|c|c|}
\hline Compound & MW & HA & AHA & RB & HBA & HBD & Rings & MSR & NC & TC \\
\hline $\mathbf{1}$ & 492.57 & 35 & 21 & 6 & 6 & 1 & 4 & 10 & 1 & -1 \\
\hline $\mathbf{2}$ & 457.88 & 32 & 16 & 5 & 5 & 1 & 3 & 10 & 1 & -1 \\
\hline $\mathbf{3}$ & 413.4 & 30 & 15 & 5 & 6 & 1 & 3 & 10 & 1 & -1 \\
\hline $\mathbf{4}$ & 389.42 & 28 & 10 & 5 & 5 & 1 & 2 & 10 & 1 & -1 \\
\hline $\mathbf{5}$ & 437.46 & 32 & 16 & 6 & 6 & 1 & 3 & 10 & 1 & -1 \\
\hline $\mathbf{6}$ & 451.49 & 33 & 16 & 6 & 6 & 1 & 3 & 10 & 1 & -1 \\
\hline $\mathbf{7}$ & 516.36 & 33 & 16 & 6 & 6 & 1 & 3 & 10 & 1 & -1 \\
\hline $\mathbf{8}$ & 487.52 & 36 & 20 & 6 & 6 & 1 & 3 & 10 & 1 & -1 \\
\hline $\mathbf{9}$ & 376.38 & 27 & 10 & 5 & 6 & 2 & 2 & 10 & 1 & -1 \\
\hline $\mathbf{1 0}$ & 374.44 & 26 & 15 & 3 & 5 & 2 & 3 & 10 & 1 & 1 \\
\hline
\end{tabular}

$\mathrm{MW}=$ molecular weight; $\mathrm{HA}=$ heavy atoms; $\mathrm{AHA}=$ aromatic heavy atoms; $\mathrm{RB}=$ rotatable bonds; $\mathrm{HBA}=$ hydrogen bond acceptors; $\mathrm{HBD}=$ hydrogen bond donors; $\mathrm{MSR}=$ maximum size ring; $\mathrm{NC}=$ number of charges; $\mathrm{TC}=$ total charge at biological $\mathrm{pH}$

Polarity, evaluated as TPSA (topological polar surface area), and lipophilicity, evaluated as $\log \mathrm{P}(\log$ arithm of the compound's partition coefficient between $n$ octanol and water), will correlate with passive transport through membranes. The aqueous solubility of a compound significantly affects its absorption and distribution characteristics. Since the drug is transported in aqueous media like blood and intracellular fluid, it has to be sufficiently water soluble. Low water solubility translates to slow absorption and action. The aqueous solubility was expressed as $\log \mathrm{S}$, where $\mathrm{S}$ is the solubility at a temperature of $20-25^{\circ} \mathrm{C}$ in $\mathrm{mol} / \mathrm{L}$. Topological polar surface area (TPSA) of all our compounds is less than $130 \AA^{2}$, an important factor in good gastrointestinal absorption. For all compounds, at least moderate water solubility is predicted. A very good solubility, the best in our current series, is predicted for compound 9. This fact can be explained by to the terminal polar unsubstituted amide moiety, which raises the polarity of the molecule, improving water solubility. The compound with the lowest solubility is predicted to be compound $\mathbf{2}$, with a solubility of $0.01 \mathrm{~g} / \mathrm{L}$. It is apparent that the chlorophenyl fragment in the molecule will increase the lipophilicity of the molecule and decrease the water solubility of the compound. Results are presented in Table III. 
Physicochemical properties, lipophilicity and water solubility of compounds 1-10

\begin{tabular}{|c|c|c|c|c|c|c|}
\hline \multirow{2}{*}{ Compound } & \multirow{2}{*}{ TPSA $\left(\AA^{\mathbf{2}}\right)$} & \multirow{2}{*}{$\operatorname{LogP}$} & \multicolumn{4}{|c|}{ Water solubility } \\
\cline { 5 - 7 } & & & $\mathbf{L o g} \mathbf{S}$ & Classification & $\mathbf{g} / \mathbf{L}$ & $\mathbf{m m o l} / \mathbf{L}$ \\
\hline $\mathbf{1}$ & 106.91 & 3.38 & -4.38 & Moderately soluble & 0.02 & 0.04 \\
\hline $\mathbf{2}$ & 82.85 & 2.65 & -4.88 & Moderately soluble & 0.01 & 0.01 \\
\hline $\mathbf{3}$ & 95.99 & 2.1 & -3.54 & Soluble & 0.12 & 0.29 \\
\hline $\mathbf{4}$ & 82.85 & 2.38 & -3.59 & Soluble & 0.1 & 0.25 \\
\hline $\mathbf{5}$ & 82.85 & 2.73 & -3.03 & Soluble & 0.4 & 0.92 \\
\hline $\mathbf{6}$ & 82.85 & 2.58 & -3.45 & Soluble & 0.16 & 0.36 \\
\hline $\mathbf{7}$ & 82.85 & 3.15 & -3.75 & Soluble & 0.09 & 0.18 \\
\hline $\mathbf{8}$ & 82.85 & 3.07 & -4.33 & Moderately soluble & 0.02 & 0.05 \\
\hline $\mathbf{9}$ & 108.87 & 1.93 & $\mathbf{- 1 . 0 2}$ & Very soluble & $\mathbf{3 6 . 1}$ & $\mathbf{9 6}$ \\
\hline $\mathbf{1 0}$ & 117.31 & 2.65 & -2.77 & Soluble & 0.63 & 1.69 \\
\hline
\end{tabular}

Neurotoxicity of fluoroquinolones is a class effect and is related to the [15] passage of the drugs across the blood-brain barrier. All our compounds are predicted not to pass the blood brain barrier [7], thus, side effects at this level may be diminished. However, a good gastrointestinal absorption is predicted in all our compounds.

P-glycoprotein (P-gp), an efflux membrane transporter, is responsible for limiting cellular uptake and the distribution of xenobiotics. P-glycoprotein is involved in antibiotic resistance by lowering the intracellular level of drugs. Fluoroquinolones have been reported as a class of drugs able to undergo efflux, which can explain the low oral bioavailability of some of them and also the emergence of quinolone resistance [43]. From our series of compounds, compounds $\mathbf{2}$ and $\mathbf{4}$ are predicted not to be a substrate of P-glycoprotein. A special warning should be mentioned, as compound 10 is predicted to be a phospholipidosis inducer (characterized by the excess accumulation of phospholipids in tissues and associated with drug induced toxicity).

Two compounds, $\mathbf{4}$ and $\mathbf{9}$ are predicted not to be inhibitors of CYP isoenzymes. This fact is very useful, because these compounds are expected not to have CYP metabolism interactions with other drugs, and also, these compounds could present a reduced hepatic toxicity risk.

Table IV

Predicted pharmacokinetics of the compounds 1-10

\begin{tabular}{|c|c|c|c|c|c|c|c|c|}
\hline \multirow{2}{*}{ Compound } & \multirow{2}{*}{ GIA } & \multirow{2}{*}{ BBBP } & \multirow{2}{*}{$\begin{array}{c}\text { Pgp } \\
\text { substrate }\end{array}$} & \multicolumn{6}{|c|}{ CYP inhibition } \\
\cline { 5 - 9 } & & & CYP1A2 & CYP2C19 & CYP2C9 & CYP2D6 & CYP3A4 \\
\hline $\mathbf{1}$ & High & No & Yes & No & Yes & Yes & Yes & Yes \\
\hline $\mathbf{2}$ & High & No & No & No & Yes & Yes & No & Yes \\
\hline $\mathbf{3}$ & High & No & Yes & No & No & Yes & No & No \\
\hline $\mathbf{4}$ & High & No & No & No & No & No & No & No \\
\hline $\mathbf{5}$ & High & No & Yes & No & No & Yes & Yes & Yes \\
\hline $\mathbf{6}$ & High & No & Yes & No & No & Yes & Yes & Yes \\
\hline $\mathbf{7}$ & High & No & Yes & No & Yes & Yes & Yes & Yes \\
\hline $\mathbf{8}$ & High & No & Yes & No & Yes & Yes & Yes & Yes \\
\hline $\mathbf{9}$ & High & No & Yes & No & No & No & No & No \\
\hline $\mathbf{1 0}$ & High & No & Yes & Yes & No & No & Yes & Yes \\
\hline
\end{tabular}

$\mathrm{GIA}=$ gastrointestinal absorption; $\mathrm{BBBP}=$ blood brain barrier permeant; $\mathrm{Pgp}=\mathrm{P}$-glycoprotein .

Analysing all the ADMET data, we can conclude that the only compound which violates one Lipinski's rule (Pfizer) is compound 7 (molecular weight $>500$ ). However, violation of one rule is accepted. Considering Lipinski (Pfizer), Veber (GSK), Muegge (Bayer) and Egan filters, all our compounds pass all the criteria. From the druggability point of view, we can outline compound 4 which has no predictable interaction with CYP enzymes or Pgp, and has a good intestinal absorption prediction, with no predicted passage at the BBB level.

\section{Molecular docking study}

DNA gyrases play a crucial role in interconversion of the DNA between the relaxed and the supercoiled forms, maintaining its normal topological state in the cell [17]. Gyrases consist from two GyrA subunits and two GyrB subunits, generating a heterotetrameric structure $\left(\mathrm{A}_{2} \mathrm{~B}_{2}\right)$ that creates the catalytically active enzyme [17]. The GyrA subunit is responsible for non-catalytic interactions with DNA, while the GyrB effectively catalyses the DNA strands cutting and rejoining. The GyrB subunit has a pocket for ATPase, 
which provides energy to the whole catalytic system, due to $\mathrm{Mg}^{2+}$-mediated ATP-hydrolysis. The ATP binding pocket has a high degree of conservation among bacteria and a low degree of homology in eukaryotic enzymes.

The graphical representation of the bacterial gyrase components is presented in Figure 2.

The absence of gyrase in the mammalian cells makes them a good target for development of novel antimicrobial drugs [17].

The tested compounds 1-10 and norfloxacin, as a standard, were docked into the catalytic site of bacterial gyrase. Their predicted binding affinity to the catalytic site of enzyme and the consequent inhibition constant (ki) of the best pose are presented in Table V.

Supplementary, in order to filter the false positive results, compounds that have less than 7 conformations in the top binding cluster and have more than 10 clusters were considered as having a high degree of dispersion binding and were considered as nonacceptable Table V.

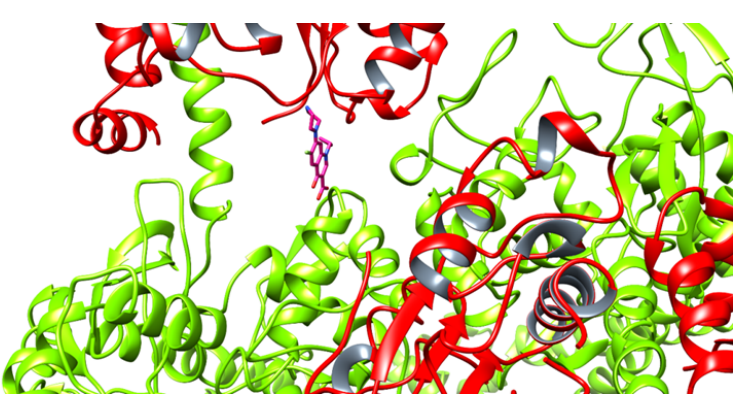

Figure 2.

Analysis of the components of the 2XCT bacterial gyrase obtained from the X-ray diffraction. In green, the A subunit and in red the B subunit of the bacterial gyrase. The interior of the ribbon helix was depicted in gray for the TOPRIM motif. In pink bars is depicted ciprofloxacin in its binding site, as it was isolated from the original protein. It is obvious the crosslinking of ciprofloxacin between A and B subunits, as presented in literature reports [28].

Table V

Predicted best binding affinity $(\Delta \mathrm{G})$ of compounds $\mathbf{1 - 1 0}$ to gyrase, the predicted inhibition constant $(\mathrm{Ki})$ and the

\begin{tabular}{|c|c|c|c|c|c|c|}
\hline \multirow{3}{*}{ Compound } & \multirow{3}{*}{$\begin{array}{c}\Delta G \\
(\mathrm{kcal} / \mathrm{mol})\end{array}$} & \multirow{3}{*}{$\mathbf{K i}(\boldsymbol{\mu M})$} & \multicolumn{3}{|c|}{ Clustering analysis } & \multirow{3}{*}{ Interpretation } \\
\hline & & & \multicolumn{2}{|c|}{ Top binding 2 Å cluster } & \multirow{2}{*}{$\begin{array}{c}\text { No. of } \\
\text { clusters }\end{array}$} & \\
\hline & & & No. of conformations & $\Delta G(\mathrm{kcal} / \mathrm{mol})$ & & \\
\hline 1 & -8.23 & 927.52 & 4 & -8.08 & 13 & Non-acceptable \\
\hline 2 & -7.12 & 6039.01 & 3 & -6.74 & 10 & Non-acceptable \\
\hline 3 & -7.26 & 4768.09 & 1 & -7.26 & 10 & Non-acceptable \\
\hline 4 & -8.44 & 650.71 & 9 & -8.36 & 4 & Acceptable \\
\hline 5 & -8.31 & 810.37 & 12 & -7.98 & 8 & Acceptable \\
\hline 6 & -8.21 & 959.36 & 7 & -7.94 & 7 & Acceptable \\
\hline 7 & -8.13 & 1098.06 & 4 & -7.96 & 12 & Non-acceptable \\
\hline 8 & -8.09 & 1174.75 & 3 & -8.04 & 12 & Non-acceptable \\
\hline 9 & -8.55 & 540.45 & 13 & -8.30 & 5 & Acceptable \\
\hline 10 & -7.67 & 2386.77 & 7 & -7.43 & 5 & Acceptable \\
\hline ciprofloxacin & -6.45 & 18710.41 & 15 & -6.36 & 4 & Acceptable \\
\hline norfloxacin & -6.74 & 11468.60 & 14 & -6.66 & 6 & Acceptable \\
\hline
\end{tabular}

Extension of the norfloxacin molecule due to derivatisation could lead to compounds with better affinity for the enzyme considering the potentially larger surface contact with the enzyme. However, although the tested compounds have good binding affinity values (Table V), it is noticeable that the binding pattern is changed compared to norfloxacin. Norfloxacin has a more homogenous binding pattern than its derivatives: the number of the conformations in the top cluster is higher and also it has less binding clusters (Table V). Norfloxacin has the same interaction with the target as seen for ciprofloxacin (Figure 2), with the crosslinking interaction between A and B subunits of DNA gyrase (Figure 3). Two important interactions are visible: the carboxyl group with Ser1084 and the piperazine moiety with Arg458.

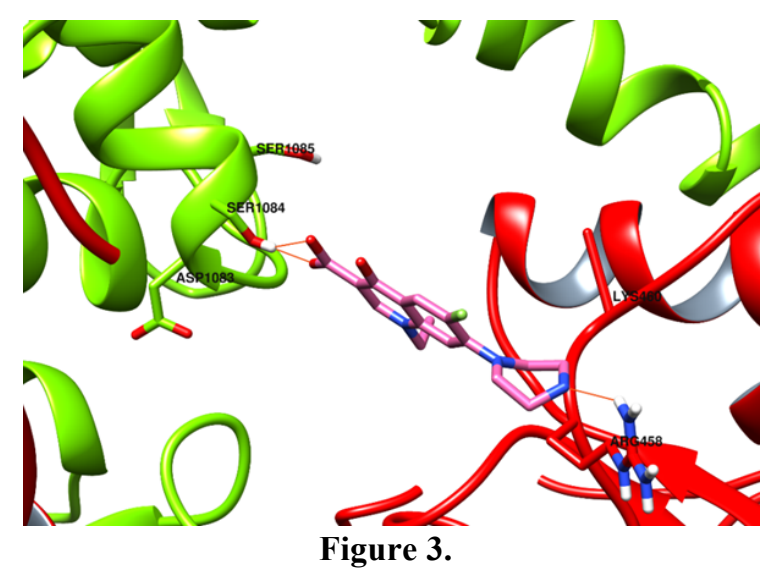

Binding mode of norfloxacin with 2XCT bacterial gyrase.

For the tested compounds 1-10, we identified two different binding patterns. 
Compounds possessing bulky residues (phenyl-thiazole in compound 1, 3-chlorophenyl in compound 2, furan in compound $\mathbf{3}, p$-bromo-acetophenone in compound 7 and naphtyl in compound $\mathbf{8}$ ) are more rigid, tend to not fit in the binding pocket of fluoroquinolones and adopt a bent conformation, without crosslinking between GyrA and GyrB. In these situations, large conformational changes appeared in the ligands, mostly due to piperazine ring bending, giving a large dispersion of binding modes. These compounds were considered as non-acceptable (Table V) and also had a low antibacterial activity (Table I).

Figure 4 exemplifies the binding mode for compound 1. The absence of the crosslinking interaction between A and B subunits of DNA gyrase is obvious.

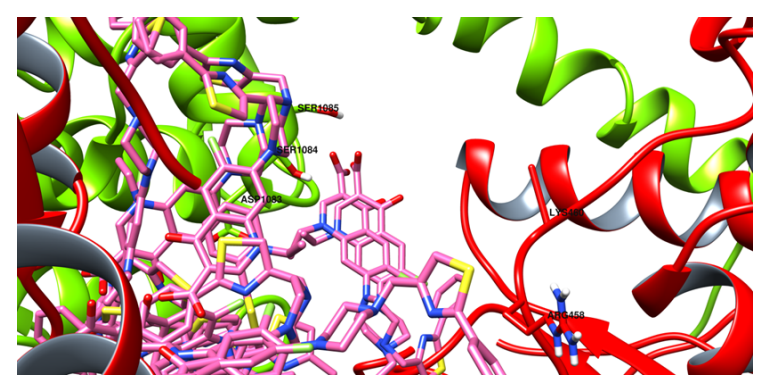

Figure 4.

The proposed binding mode of the compound $\mathbf{1}$

Derivatives with smaller residues, such as isobutyloxy, unsubstituted acetophenone, amide or thiadiazole (compounds 4, 5, 6, 9 and 10), tend to have a similar binding pattern with the parent compound (norfloxacin) and thus presented crosslinking interaction between GyrA and GyrB. Figure 5 and Figure 6 exemplify the proposed binding mode for compounds 9 and $\mathbf{1 0}$.

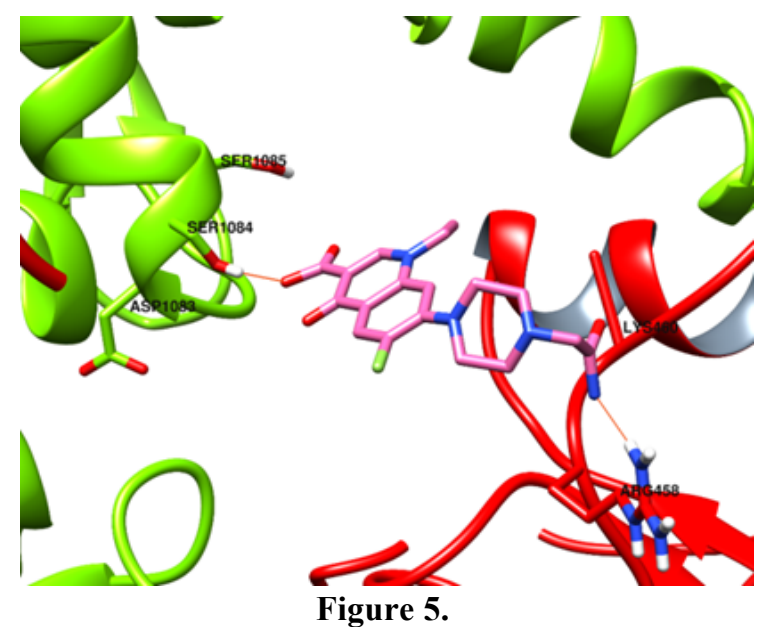

Binding mode of compound 9

A particular binding mode was exhibited by compound 10, which has the carboxyl group replaced with an amino-thiadiazole moiety. For this compound the interaction with Ser1084 is not possible due to the absence of the carboxyl group, but the amino group of thiadiazole nucleus, interacts with the Asp1083, making possible the crosslinking interactions with the enzyme (Figure 6).

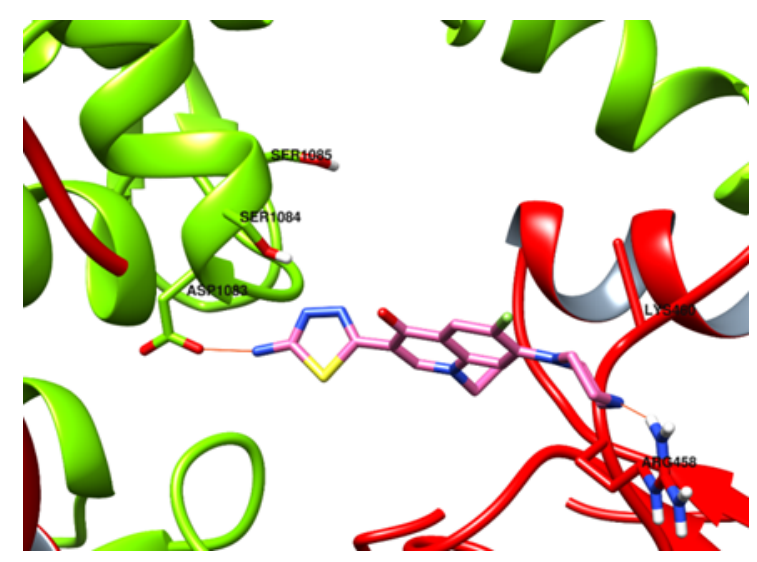

Figure 6.

Binding mode of compound $\mathbf{1 0}$

\section{Conclusions}

Different types of synthetic modifications on the norfloxacin scaffold were carried out and the obtained derivatives were characterized by spectroscopic techniques like ${ }^{1} \mathrm{H}$ NMR and MS. The obtained compounds were tested for their antibacterial potential against Gram-positive and Gram-negative bacteria. Some of the tested compounds showed a good antibacterial activity, expressed mainly against Grampositive bacteria (e.g. S. aureus strain). The results of the antimicrobial screening showed that the type of substituent can influence antimicrobial activity (the substitution with bulky residues seems to be less favourable for the antibacterial activity).

The target compounds also had good predicted pharmacokinetic properties following ADMET analysis. Furthermore, the molecular modelling study revealed the binding mode of the target compounds to the active site of DNA gyrase. The results of the molecular docking study identified the structural features that can influence the binding affinity of the compounds to the enzyme: the position of the substituent on the norfloxacin scaffold and the volume of the substituent.

\section{Acknowledgement}

This work was supported by a grant of the Romanian National Authority for Scientific Research and Innovation, CCCDI-UEFISCDI project number 28 BM.

\section{References}

1. *** Performance Standards for Antimicrobial Susceptibility Testing; $22^{\text {nd }}$ Informational Supplement document M100S22, 2012; 32: 140-162.

2. Abu-Qatouseh L, Abu-Sini M, Mayyas A, Al-Hiari Y, Darwish R, Aburjai T, Synthesis of new nitrofluoroquinolone derivatives with novel anti-microbial 
properties against metronidazole resistant H. Pylori. Molecules, 2017; 22(1): 1-11.

3. Abuo-Rahma GEDAA, Sarhan HA, Gad GFM, Design, synthesis, antibacterial activity and physicochemical parameters of novel N-4-piperazinyl derivatives of norfloxacin. Bioorg Med Chem., 2009; 17(11): 3879-3886.

4. Borcea AM, Marc G, Pîrnău A, Vlase L, Ionuț I, Tiperciuc B, Oniga O, Synthesis and molecular docking study of some new 4-phenylene-bisthiazoles as fungal lanosterol $14 \alpha$-demethylase inhibitors. Farmacia, 2017; 65(5): 683-689.

5. Chen YL, Fang KC, Sheu JY, Hsu SL, Tzeng CC, Synthesis and antibacterial evaluation of certain quinolone derivatives. $J$ Med Chem., 2001; 44(14): 2374-2377.

6. Daina A, Michielin O, Zoete V, SwissADME: a free web tool to evaluate pharmacokinetics, druglikeness and medicinal chemistry friendliness of small molecules. Sci Rep., 2017; 7: 42717: 1-13.

7. Daina A, Zoete V, A BOILED-Egg to Predict Gastrointestinal Absorption and Brain Penetration of Small Molecules. Chem Med Chem., 2016; 11(11): 1117-1121.

8. Drlica K, Mustaev A, Towle TR, Luan G, Kerns RJ, Berger JM, Bypassing Fluoroquinolone Resistance with Quinazolinediones: Studies of Drug-GyraseDNA Complexes Having Implications for Drug Design. ACS Chem Biol., 2014; 9(12): 2895-2904.

9. Egan WJ, Merz KM, Baldwin JJ, Prediction of Drug Absorption Using Multivariate Statistics. $J$ Med Chem., 2000; 43(21): 3867-3877.

10. Gómez CMM, Kouznetsov VV, Recent Developments on Antimicrobial Quinoline Chemistry. Microb Pathog Strateg Combat Them Sci Technol Educ., 2013; 1: 666-677.

11. Goswami M, Mangoli S, Jawali N, Importance of chemical modification at $\mathrm{C}-7$ position of quinolones for glutathione-mediated reversal of antibacterial activity. Int J Antimicrob Agents, 2014; 43(4): 387-388.

12. Gould IM, Bal AM, New antibiotic agents in the pipeline and how hey can help overcome microbial resistance. Virulence, 2013; 4(2): 185-191.

13. Idowu T, Schweizer F, Ubiquitous Nature of Fluoroquinolones: The Oscillation between Antibacterial and Anticancer Activities. Antibiotics, 2017; 6(4): $1-24$.

14. Jones TM, Johnson SW, Dimondi VP, Wilson DT, Focus on JNJ-Q2, a novel fluoroquinolone, for the management of community-acquired bacterial pneumonia and acute bacterial skin and skin structure infections. Infect Drug Resist., 2016; 9: 119-128.

15. Kamath A, Fluoroquinolone Induced Neurotoxicity: A Review. J Adv Pharm Educ Res., 2013; 3(1): 16-19.

16. Khan KM, Siddiqui R, Ambreen N, Sultana N, Tauseef S, Ahmad A, Perveen S, Synthesis, antibacterial, and antifungal evaluation of norfloxacin derivatives. J Pharm Res., 2012; 5(1): 666-671.

17. Khan T, Sankhe K, Suvarna V, Sherje A, Patel K, Dravyakar B, DNA gyrase inhibitors: Progress and synthesis of potent compounds as antibacterial agents. Biomed Pharmacother., 2018; 103: 923-938.

18. Kitchen DB, Decornez H, Furr JR, Bajorath J, Docking and scoring in virtual screening for drug discovery: methods and applications. Nat Rev Drug Discov., 2004; 3(11): 935-949.

19. Kocsis B, Domokos J, Szabo D, Chemical structure and pharmacokinetics of novel quinolone agents represented by avarofloxacin, delafloxacin, finafloxacin, zabofloxacin and nemonoxacin. Ann Clin Microbiol Antimicrob., 2016; 15(1): 1-8.

20. Lagorce D, Sperandio O, Baell JB, Miteva MA, Villoutreix BO, FAF-Drugs3: a web server for compound property calculation and chemical library design. Nucleic Acids Res., 2015; 43: 200-207.

21. Lee JW, Kim NH, Kim EJ, Heo H, Jung YJ, Lee JR, Park YH, Park SC, Jang MK, Enhanced of norfloxacin bioavailability using conjugation of isosorbide via enzymatic catalysis. Biotechnol Bioprocess Eng., 2016; 21(4); 508-514.

22. Lipinski CA, Lombardo F, Dominy BW, Feeney PJ, Experimental and computational approaches to estimate solubility and permeability in drug discovery and development settings. Adv Drug Deliv Rev., 2001; 46: 3-26.

23. Makeneni S, Thieker DF, Woods RJ, Applying Pose Clustering and MD Simulations to Eliminate False Positives in Molecular Docking. $J$ Chem Inf Model, 2018; 58(3): 605-614.

24. Malik M, Mustaev A, Schwanz HA, Luan G, Shah N, Oppegard LM, de Souza EC, Hiasa H, Zhao X, Kerns RJ, Drlica K, Suppression of gyrase-mediated resistance by $\mathrm{C} 7$ aryl fluoroquinolones. Nucleic Acids Res., 2016; 44(7): 3304-3316.

25. Marc G, Ionuț I, Pirnau A, Vlase L, Vodnar DC, Duma M, Tiperciuc B, Oniga O, Microwave assisted synthesis of 3,5-disubstituted thiazolidine-2,4-diones with antifungal activity. Design, synthesis, virtual and in vitro antifungal screening. Farmacia, 2017; 65(3): 414-422.

26. Morris GM, Huey R, Lindstrom W, Sanner MF, Belew RK, Goodsell DS, Olson AJ. AutoDock4 and AutoDockTools4: Automated Docking with Selective Receptor Flexibility. J Comput Chem., 2009; 30(16): 2785-2791.

27. Muegge I, Heald SL, Brittelli D, Simple Selection Criteria for Drug-like Chemical Matter. J Med Chem., 2001; 44(12): 1841-1846.

28. Mustaev A, Malik M, Zhao X, Kurepina N, Luan G, Oppegard LM, Hiasa H, Marks KR, Kerns RJ, Berger JM, Drlica K, Fluoroquinolone-Gyrase-DNA Complexes. J Biol Chem., 2014; 289(18): 12300-12312.

29. Neill JIMO. Tackling Drug-Resistant Infections Globally: Final Report and Recommendations the Review on 2016.

30. Pettersen EF, Goddard TD, Huang CC, Couch GS, Greenblatt DM, Meng EC, UCSF Chimera-A visualization system for exploratory research and analysis. J Comput Chem., 2004; 25(13): 1605-1612.

31. Pintilie L, Quinolones: Synthesis and Antibacterial Activity. Antimicrob Agents, 1991; 9: 255-272.

32. Podos SD, Thanassi JA, Leggio M, Pucci MJ, Bactericidal activity of ACH-702 against nondividing and biofilm staphylococci. Antimicrob Ag Chemother., 2012; 56(7): 3812-3818.

33. Prestinaci F, Pezzotti P, Pantosti A, Antimicrobial resistance: a global multifaceted phenomenon. Pathog Glob Health, 2015; 109(7): 309-318. 
34. Redgrave LS, Sutton SB, Webber MA, Piddock LJV, Fluoroquinolone resistance: Mechanisms, impact on bacteria, and role in evolutionary success. Trends Microbiol., 2014; 22(8): 438-445.

35. Sales EM, Figueroa-Villar JD, Recent Studies about Synthesis and Biological Activity of Quinolones and Derivatives: A Review. World J Pharm Pharm Sci., 2016; 5(8): 253-268.

36. Schwanz HA, Structural features of fluoroquinoloneclass antibiotics that affect lethal activities and DNA binding. Iowa Res. Online, Univ. Iowa Repos., 2012: 1-206.

37. Sharma PC, Jain A, Yar MS, Pahwa R, Singh J, Goel $\mathrm{S}$, Synthesis and antibacterial evaluation of novel analogs of fluoroquinolones annulated with 6substituted-2-aminobenzothiazoles. Arab J Chem., 2015; 8(5): 671-677.

38. Sultana N, Arayne MS, Bushra S, Rizvi S, Mesaik MA, Synthesis, Characterization and Biological Evaluation of a Series of Levofloxacin Carboxamide Analogues. Bull Korean Chem Soc., 2009; 30(10): 2294-2298.
39. Valadbeigi E, Ghodsi S, Synthesis and Characterization of Some New Thiazolidinedione Derivatives Containing a Coumarin Moiety for their Antibacterial and Antifungal Activities. Med Chem (Los Angeles), 2017; 07(06): 554-564.

40. Veber DF, Johnson SR, Cheng HY, Smith BR, Ward $\mathrm{KW}$, Kopple KD, Molecular properties that influence the oral bioavailability of drug candidates. $J$ Med Chem., 2002; 45(12); 2615-2623.

41. Venepally V, Prasad RBN, Poornachandra Y, Kumar CG, Jala RCR, Synthesis of novel ethyl 1-ethyl-6fluoro-7-(fatty amido)-1,4-dihydro-4-oxoquinoline3-carboxylate derivatives and their biological evaluation. Bioorg Med Chem Lett., 2016; 26(2): 613-617.

42. World Health Organisation. Antibacterial Agents in Clinical Development. Who/Emp/Iau/2017.12: 48.

43. Yamaguchi H, Yano I, Saito H, Inui K, Pharmacokinetic Role of P-Glycoprotein in Oral Bioavailability and Intestinal Secretion of Grepafloxacin in Vivo. $J$ Pharmacol Exp Ther., 2002; 300(3): 1063-1069. 